\title{
The role of amateur and professional judges in the royal courts of late medieval England
}

\author{
Anthony Musson
}

The thirteenth and fourteenth centuries witnessed a rapid expansion in the scope of royal justice in England. The growing demand for legal remedies and the need to enforce public order led to an expansion in the activities of the Westminster courts and in the increasing provision of judicial commissions (some ad hoc, others on a more regular basis) in the shires. ${ }^{1}$ The expansion was inevitably accompanied by the need for a body of men willing and able to assist in interpreting the law and managing the complexities of litigation both in the central courts and in the sessions held in the provinces. A detailed examination of the personnel involved in royal justice would not be appropriate here, but this chapter will endeavour to provide an overview of the dynamics of the administration of justice in late medieval England and an insight into the judiciary at work.

The perception that justices engaged under royal commissions were either 'amateurs' or 'professionals' has to some extent reflected a conceptual division between 'local' and 'central' justice frequently invoked in the context of the emergence of the local magistracy and the staffing of other royal tribunals in the thirteenth and fourteenth centuries. Put at its starkest, those acting in the central courts have tended to be regarded as 'professionals', while the justices of the peace have traditionally been seen as constituting the amateur wing of the judiciary. In many ways the distinction has arisen as a result of the directions taken in historical research. Historians of the legal profession have been drawn towards the personnel of the central courts, mainly because of the quality and quantity of surviving evidence relating to the Courts of Common Pleas and King's Bench, but also out of a preconceived idea of what constituted the legal profession. ${ }^{2}$ The distinction has been perpetuated in the significant corpus of research on the development of the justices of the peace, which has concentrated on the magistracy at the expense of the wider judicial context, and emphasises the supposed tension between the locally based men who served on judicial commissions and the 'professional' justices 
of the central courts. ${ }^{3}$ It is only since the last decade or so of the twentieth century that this supposed dichotomy has been reviewed and that the significant contribution to local justice by provincially based practitioners has been recognised. ${ }^{4}$

This chapter offers a refocusing of the divergent historiographical trends, arguing against an artificial separation between 'central' and 'local' justice and questioning the conventional notion of a dichotomy between the "professional' element drawn from the central courts and the 'amateur' contingent recruited from the shires. It suggests that for a variety of reasons there was a blurring of distinctions between the personnel involved in the administration of justice and that there was a broader culture to the legal profession than usually acknowledged, reflecting a considerable overlap of expertise between those traditionally labelled as 'professionals' (lawyers) or 'amateurs' (county gentry). Analysis of the personnel within the broad arena of judicial administration (not just of the central courts or the peace commissions) reveals that those (most, if not all) undertaking judicial tasks possessed a certain level of legal knowledge and justifiably ought to be credited as 'men of law'. This term is justified in contemporary practice where it appears in various parliamentary petitions and statutes (albeit somewhat ambiguously) to describe both lawyers of the central courts and county-based ones. In the later fourteenth century it was a label increasingly applied to those who were "working justices' in the quorum at peace commissions, but who (as a result of professional demarcation on the part of central court justices) were not assize justices. In 1352, for example, it was suggested that the peace commissions in general should comprise loyal, local men who had knowledge of the law: in other words, it was assumed that the majority, if not all of the king's justices should have some understanding of legal process and administration. It is significant, therefore, that an unofficial abstract of the first chapter of the 1361 statute (now known as the Justices of the Peace Act), drawn up in about 1362, substitutes sages de la ley for hommes de ley: the implication being that it was not necessary to be a trained lawyer (homme de ley) merely to be 'wise' in the ways of the law (sage de la ley). ${ }^{5}$

In the thirteenth century the justices appointed to the central courts (and the eyre) came from a variety of backgrounds and possessed differing levels of experience. A dominant tendency was for the clerks of serving judges to move up to one of the benches or become eyre justices, thus creating what have been described as 'judicial dynasties'. Martin Pateshull, for example, was succeeded by his clerk, William Raleigh, who was followed by his clerks, Roger Thirkelby and Henry Bracton. Ralph Hengham and Hervey Stanton also followed this route. Hengham, a protégé of Giles Erdington (serving as his clerk from 1258), became a justice of Common Pleas in $1273 .{ }^{6}$ Some of the justices appointed to the benches had links with the Exchequer or were members of county society with extensive experience of local justice, such as John de Cobham and Robert Malet. ${ }^{7}$ On a number of occasions the appointed bench 
justices were joined or supplemented by colleagues drawn from other branches of administration. In 1234, for instance, William Raleigh, puisne judge of the King's Bench, was sometimes assisted by stewards of the royal households. Between 1258 and 1264 the chief justiciar sat in King's Bench. ${ }^{8}$ In the later years of Edward I, senior clerks of the Common Bench occasionally heard cases alongside one or more of the justices, ${ }^{9}$ suggesting that legal knowledge or simply administrative exigencies could hold sway over formal requirements.

A new trend in the composition of the central courts is observable from the closing decade of Edward I's reign, concomitant with changes in the structure of the legal profession. From the 1290s the justices appointed to the higher judiciary were increasingly drawn from the small group of serjeantsat-law who had by this time gained a monopoly over pleading in the central courts. This avenue of promotion to the bench was regularised during Edward II's reign, when two-thirds of serjeants followed it. In the period 1315-77 three-fifths of all king's serjeants reached the bench..$^{10}$ Experience in provincial administration continued to be a qualification for appointment to one of the benches (as in the case of Robert Baynard), ${ }^{11}$ though after Edward III's personal assumption of power in the 1330s it became an extremely rare phenomenon. ${ }^{12}$

The justices of the central courts played an equally important role in provincial justice, not just through the visitations of the eyre, but through their presence on commissions of assize and gaol delivery and on ad hoc commissions of general and special oyer and terminer. From Edward II it was common to find the serjeants and justices of the central courts staffing the assize circuits. In the fourteenth century they also became associated with the peace commissions either as justices of the peace in their own right, or as members of separate commissions to try indictments, or (from 1340s) in their capacity as assize justices, as part of the quorum. Looking from one end of the spectrum, therefore, from the perspective of the central courts, there was considerable involvement and investment of personnel in 'local' justice. ${ }^{13}$

Like their counterparts, the county-based commissioners were not a homogenous group and had different aspirations and degrees of experience. The experience and technical knowledge of men of law operating in the provinces, however, has been seriously underestimated by historians and is seldom acknowledged. In her monograph on the royal judge William Shareshull, Bertha Putnam, for instance, dismissed the appointment in 1329 of John Annesley as Shareshull's sole colleague on the western assize circuit: 'Apparently [Annesley] was not even a serjeant-at-law; therefore in taking assizes and delivering gaols it must have been Shareshull's legal knowledge that was relied upon.' She does not consider the fact that some commissions contained no central court justices upon whose legal knowledge they could supposedly rely. ${ }^{14}$ Local men such as Robert Madingley, Richard Rodney and Hugh Wake would not and could not have conducted assize sessions unless they had a thorough grounding in the intricacies of land law. ${ }^{15}$ This underestimation 
stretches to the justices of the peace. The commissions with full powers to try offences issued after the Black Death have been seen by some historians as providing the watershed of the judicial involvement of the justices of the peace, ${ }^{16}$ but this view negates the role played by 'men of law' in the judicial process prior to the Black Death (particularly as justices of gaol delivery in the thirteenth and early fourteenth centuries) and ignores the variety of commissions on which many of them served, whether as justices of general and special oyer and terminer, or as justices of labourers. ${ }^{17}$

As the fourteenth century progressed it is apparent that the increasing burden of judicial work devolving on the peace commissioners became an outlet for the experience of county-based lawyers. From the 1350s there were two developments which have considerable bearing on perception of the peace commissions. First, the personnel of the commissions increased in size over the later fourteenth and fifteenth centuries. While in earlier years the small size of commissions meant that those appointed generally acted, the expansion meant that a number of these positions were purely honorific. Secondly, the responsibility for trying offenders was concentrated in the hands of the 'quorum', a select group of named men (usually assize justices). In practice local 'men of law', such as Walter Haywode (Hampshire JP and steward to the prior of St Swithin's, Winchester) and Walter Clopton (Somerset JP and steward to the bishop of Bath and Wells) regularly entertained all manner of offences at peace sessions and duly put forward for trial indictments for felony, ${ }^{18}$ sometimes also trying the offences that came before them. ${ }^{19}$ Analysis of the personnel of the peace commissions in Suffolk and Gloucestershire between 1382 and 1389, when the commissions were considerably enlarged in the aftermath of the Peasants' Revolt, reveals that the expansion was chiefly the addition of lawyers active in local administration. In 1389 and 1394, the same men were formally recognised as having a distinctive role by receiving statutory sanction to act in the place of justices of assize when first trespasses, and then all cases, including felonies, were brought to judgment. ${ }^{20}$ By the fifteenth century, the bulk of the work of the quarter sessions had fallen to this group composed of the most substantial men of legal training resident in the county. ${ }^{21}$ This was still the case in the mid-fifteenth century, when the justices of the peace named as sitting at gaol deliveries (only ever a selection of those on the peace commission) were present "not merely as interested onlookers' but in recognition that they were those most heavily involved in legal business in the county. ${ }^{22}$

A development which profoundly affected the personnel of the judiciary and influenced the identity of the legal profession was the transition from benches comprising men in holy orders to panels of non-clerical judges. Although it could be argued that the shift from clerical to lay justices represented a move towards greater professionalisation, that would be to adopt a rather superficial view of the change, since a number of influential legal figures of the late 
twelfth and thirteenth centuries such as Hubert Walter and Martin Pateshull and Ralph Hengham were in holy orders. The move was one that reflected the new routes of promotion that were occurring in the upper circles of the legal profession. ${ }^{23}$

In 1179 the Third Lateran Council prohibited ecclesiastics sitting as secular judges. In spite of the legislation, the change was extremely gradual and little serious effort was made to exclude those in holy orders. Henry II had encouraged a mixture of clerics and laymen on judicial panels and a coterie of justices who were laymen came to prominence under John, among them the influential Simon Pateshull. ${ }^{24}$ A more vigorous campaign was waged from the early thirteenth century. Master Thomas of Chobham, for instance, in his Summa confessorum (c. 1216), warned against the sentencing of men to death or mutilation by clerics, urging that 'So great is the dread of human blood that even a judge who justly slays the wicked, if he enters the religious life or wishes to be made a cleric, cannot be promoted to holy orders. ${ }^{25}$ On a more formal level, the Fourth Lateran Council denounced the involvement of clerics in judgments of blood and much English diocesan legislation was promulgated during the early thirteenth century reflecting a similar concern. Indeed, under Henry III the involvement of clerical justices in secular cases was part of a wider campaign for the withdrawal of the clergy from secular government entirely. Arguments were put forward by Richard Grant, archbishop of Canterbury, and Robert Grosseteste, bishop of Lincoln, among others, against the intermixing of spiritual and temporal responsibilities (particularly judgments of blood), which could be held either directly as an employee of the royal courts or indirectly through the exercise of franchisal jurisdiction. The quo warranto inquiries reveal that several ecclesiastics possessed gallows or rights of infangthief. ${ }^{26}$ In spite of these warnings and prohibitions, many prominent judges of the thirteenth century who were clerks in holy orders holding benefices with care of souls - among them Martin Pateshull, William Raleigh, Henry Bracton, Roger Thirkleby, Hervey Stanton and Ralph Hengham - held sessions of the general eyre and gaol delivery at which they would have been required to impose the death penalty. William Raleigh even had cases of felony adjourned for his personal hearing. ${ }^{27}$ The role of clerks in royal justice was clearly a tenacious one.

While the spiritual prohibitions may have fallen on deaf ears, a decisive change in clerical involvement in judgments of blood came in 1299 following the royal government's Statute of Fines. The statute enacted that for criminal trials, a local knight should be associated with one of the assize justices (who under the statute had assumed jurisdiction over gaol delivery) if the other assize justice was in holy orders. Unlike the earlier ecclesiastical legislation, this particular clause was acted upon and had considerable impact on the involvement of local men of law in provincial royal justice. Irrespective of whether one of the assize justices was a cleric, local men were associated with one of the assize justices at gaol delivery. ${ }^{28}$ The clause did not spell the end of 
clerical involvement in justice altogether as some chancery clerks were still commissioned to hold assizes and deliver gaols, but although they sat at assizes there is no evidence that they participated in judgments of blood. ${ }^{29}$ The shift away from clerical involvement in gaol delivery and oyer and terminer cases was mirrored by changes in the composition of the central courts. Under Edward II, Gilbert Rothbury and Lambert Trykingham were puisne judges in holy orders, but only one of five chief justices of King's Bench (Hervey Stanton) was a cleric. By Edward III's reign clerics holding judicial positions in the central courts had virtually become a thing of the past. ${ }^{30}$

The peace commissions of the later fourteenth and fifteenth centuries reserved places for spiritual leaders in recognition of their place in local society. It should be emphasised, however, that these positions were purely honorific and such figures rarely, if ever, sat at actual sessions. Nevertheless there are some examples of a continued clerical involvement in lay justice, albeit under unusual circumstances. The Scottish frontier provided one such context and Bishop Appleby of Carlisle, one of the wardens of the royal march, was expected to perform his duties and turn up at court sessions in spite of his reservations at the weight of business and its suitability for a clergyman. In the context of Scottish border peace commissions, one of the first appointments to the post1344 style 'quorum' for the march area in 1373 was the civil lawyer, Master John Appleby, dean of St Paul's Cathedral in London. ${ }^{31}$ The presence of William Alnwick, bishop of Lincoln, at peace sessions in Bedfordshire in 1437 was probably intended to enhance the standing of the commission and impress his authority and impartiality on those who had taken part in the so-called Bedford riots. ${ }^{32}$

Having ascertained the character and composition of the various benches, it is necessary to consider the manner in which judges conducted the trial proceedings and the extent of their direct participation in the business before them. What role did they play in the trial itself? The justices were present to interpret the law and uphold custom of the court. Adjudication on matters of fact was primarily a matter for the jury. In what we might anachronistically (albeit conveniently) refer to as civil trials the jury were presented with a question either on the basis of the original writ initiating the proceedings or as a result of the defendant's pleadings. Their answer in some cases could conclude the proceedings without the need for a decision on the substantive legal issue..$^{33}$ In criminal trials the traditional orthodoxy maintains that the jury came to the trial already apprised of the matter since they were drawn from the neighbourhood where the offence was committed and so were able to make a decision on the details contained in the accusation. ${ }^{34}$

Can we discern or distinguish the activities of those county-based "men of law' acting in a judicial capacity? It is difficult to discern any active role in the proceedings played by any of the justices since the plea rolls are silent on all but the essential details and even cast a veil of anonymity over the judgment. 
In civil trials the judgment recorded in the plea rolls as issued by the justices (prefaced by the words consideratum est or iudicium est) consists either of a simple statement of the consequences of the jury's decision or more usually a repetition of the jurors' findings together with the amount of damages (calculated by the jury) and an indication of the consequences. For instance in an assize of novel disseisin held in 1317 before Lambert Trykingham, John Chaynel and Nicholas Bolingbroke at Boston (Lincolnshire) between William Clerk of Kyme and John Pylot of Lafford (in which it was alleged that the former had disseised the latter of a plot of land 243 feet by one and a half feet) the assize jury said that William was unjustly disseised, but that in fact the piece of ground measured about 226 feet by one and a half and added that William (with John's consent) had built a wall seventeen feet long, which was on his own property, not dividing it, as he had claimed. The justices then provided judgment ('it was considered that John recover his seisin') summing up the substance of the jury's answer and their award of 30s in damages, adding further that William was in mercy (liable to amercement) and that John would be amerced for the part of his claim that was false. ${ }^{35}$ Sometimes the jury provided its version of the facts, but then prayed 'the learning of the court', leaving the justices to decide the legal issue. ${ }^{36}$ The request for the court to exercise its discretion was permissible in actions of novel disseisin under the second Statute of Westminster (1285) $)^{37}$ and was occasionally also broached in trespass cases where the jury were unsure of the application of the law or the issue put to them. The judges were reticent, however, about allowing juries special verdicts in many other types of action. As Chief Justice Bereford urged on one occasion in Edward II's reign, when a jury was reluctant to offer a verdict: 'Good people, tell us what you think (Bonez gentz dites ceo qe vous scentez). ${ }^{38}$

The laconic nature of the plea roll entries is compensated to a considerable degree by the reports of cases made for private reference or teaching purposes that comprise the Year Books. ${ }^{39}$ These unofficial accounts are an important source of information on the medieval trial and provide a much fuller picture of the royal judges in action, giving the names of the speakers, the legal discussion occurring in court and the various points of law coming from the bench. ${ }^{40}$ The cases contained in these reports arise from proceedings held in the eyre or the Court of Common Pleas or sometimes the Court of King's Bench. As such they tend to exemplify the higher judiciary at work, rather than the countybased justices. The only insight into the work of the latter is therefore the plea rolls, from which it is difficult to gauge their individual legal input.

To what extent and to what end did the justices interact with other participants in court such as parties, counsel, witnesses, officials, members of the jury? The reports covering the central courts show how the justices interacted with the serjeants pleading before them, engaging in legal debate on points of law and procedure ${ }^{41}$ At times they display a sense of humour, which comes across in such a way that it is easy to imagine Bereford with a twinkle in his 
eye. ${ }^{42}$ The justices could also be intimidating both to counsel and their attorneys alike and frequently no quarter was spared. In 1289, for instance, John Lovetot urged one of the serjeants to 'Answer over or we will say something you will not wish to hear. ${ }^{, 43}$ Warnings concerning pleading were frequently given, ${ }^{44}$ though this was clearly the justices' way of managing proceedings and keeping discipline in court. In 1335 Chief Justice Herle became so exasperated by the tactics of one of the serjeants appearing before him that he urged him to "plead your plea first and then argue: for otherwise you are driving the plough before the oxen' ${ }^{45}$ There is also some evidence to show that the judges' control of the proceedings was not wholly verbal: a wink, a nod, a gesture or a glance could suffice either to encourage or to warn. ${ }^{46}$

The nature of the proceedings and the direction that they took often necessitated interaction with the jury. Usually this would be for amplification of their answers to factual questions. Fed up with the jury's apparently evasive answers whilst hearing an assize of mort d'ancestor in 1293, Roubury bullied them into an answer by saying, 'You shall tell us in another way how he was the next heir or you shall remain shut up without eating and drinking until tomorrow morning. ${ }^{, 47}$ While such a threat may appear harsh (and perhaps was intended merely as a threat) the justices were well within their rights, since the rule regarding jury deliberations was that they should be locked up without drink or sustenance and with no human contact except a guard until their verdict was reported to the court. In 1389, when a plaintiff brought a motion for a new trial (alleging that the jury deciding his case had been in the town eating and drinking before reporting the outcome of their deliberations to the court), the judges questioned the jurors carefully on the circumstances of their apparent breach. ${ }^{48}$

The justices on occasion called in witnesses or questioned the plaintiff or defendant themselves, speaking directly to the individual (rather than to his or her attorney or pleader)..$^{49}$ In one case, Bereford spoke directly to a witness, asking him whether he had leased the tenements as alleged and then made a quitclaim, to which the witness, Richard (the tenant), then replied. ${ }^{50}$ Where it was alleged that the tenant had not received a summons to court, the two persons returned as summoners were examined by the court and informed of the law of the land regarding the service of valid summonses. ${ }^{51}$ The reports dating from the late thirteenth and fourteenth centuries reveal that the justices occasionally directed their comments to 'apprentices of the bench', who were listening to and studying the proceedings from a vantage point in the courtroom (en le cribbe). ${ }^{52}$ This might take the form of a mini-lecture while the serjeants were away from the bar consulting their clients, ${ }^{53}$ or the deliberate underlining of a point made in court. ${ }^{54}$ At one point Bereford told a serjeant that he was grateful for his challenge "not for the sake of us who sit on the bench, but for the sake of the young men (les joevens) who are here'. ${ }^{55}$

In forming their judgment the justices sometimes needed to confer with each other or with colleagues sitting in other courts. In 1388, for instance, 
a particular issue was debated by the justices and the court for a long time (et ceo mater longe temps debate par les Iustices et la court)..$^{56}$ In 1338 it is reported that 'Scot came into the common bench and asked the opinions of Shareshull, Hillary and Aldeburgh in pursuance of whose opinions the others gave judgment that the defendant should be convicted because they pleaded not guilty when they might have justified their act. ${ }^{57}$ Shareshull was once criticised by his companions for adjudging in haste a writ to be good, but later the justices said that they were agreed beforehand on the same judgment. ${ }^{58}$ Advice was sometimes sought from the king's council. In 1338 Herle and all the most learned of the king's council agreed that an inquest was joined contrary to law and reason. ${ }^{59}$ When one of the justices had been absent from court it was necessary to interrupt the proceedings to allow him to confer with his colleagues and receive an update on the case. ${ }^{60}$ There were also occasions when it was necessary for the court to request copies of official texts which would then have to be produced in court to enable the justices to make an informed decision. This usually entailed reference to the clauses of certain statutes ${ }^{61}$ or an inspection of entries in Domesday Book. ${ }^{62}$

The court was not always united in its opinion or on the most appropriate way to proceed in an action and there could be mild disagreement between the judges sitting. For example, Chief Justice Bereford, in response to his colleague John Mutford's comment that certain members of the court had said 'a great deal that runs counter to what was hitherto accounted law', concurred, but then added (perhaps markedly) 'and I will not say who they are' (presumably because they knew well enough). ${ }^{63}$ In another case, this time from Edward III's reign, Willoughby recalled that 'a man made his plaint for common turbary to burn the turf in a messuage and to sell it at his pleasure and this cannot be said to be appendant by prescription and [yet] it was maintained'. His colleague Shareshull tried to correct him saying, 'That is not law now.' But Willoughby apparently retorted with the ultimate conversation stopper: 'One more learned than you are adjudged it. ${ }^{64}$

Disturbances during sessions or offences occurring within the courtroom area 'in the presence of the justices' could lead to immediate action being taken. Pickpockets or cutpurses caught operating in the busy Westminster Hall could face immediate trial with a jury summoned from the bystanders ${ }^{65}$ while insulting the justices as they were about to take their seats could result in a contempt of court action. In one such case which had been brought by the King's Bench justice Robert Scardburgh against William Botevileyn and his wife, Margery, the court acted quickly, but was careful to be informed of the contempt in the correct legal manner (normally by a confession from the offender or a bill of trespass or if possible a verdict from a jury of by-standers) before proceeding to judgment. Once Margery had (finally) admitted the trespass at the bar of the court, she was re-committed to the custody of the Marshal and released on mainprise (bail). ${ }^{66}$ 
While the clerk's record of criminal trials is generally only a couple of lines offering merely the essential details, lending credence to the view that the trial itself was comparatively brief, ${ }^{67}$ it is clear from the surviving records that the justices did not sit there wholly passive, merely awaiting and accepting the jury verdict. ${ }^{68}$ The justices had a positive role to play and (depending upon the nature of the indictment, the type of case and the defendant's plea) needed to have a keen awareness of procedural aspects as well as of substantive matters. They were called upon to use their knowledge and experience to spot faults in the indictments that came before them. The justices might query the terms (de forma) of the indictment ${ }^{69}$ as they themselves could be held to be in error if an indictment was allowed to proceed that was later found to be incompetent or imprecise. ${ }^{70}$ The gaol delivery justices adjourned the trial of John Kykel of Thorpe in Norfolk (indicted for burglary) because his indictment did not specify any year or day and had been taken in the absence of the oath and seals of the twelve jury members. ${ }^{71}$ In the case of Clement Gorlast of South Reppes, whose indictment (merely stating that he was a common thief of sheep) was felt to be too vague, the justices asked the jury to expand on this and name any specific thefts (which they could not). ${ }^{72}$ Even if the accused were present in court, the justices might delay his or her trial if they did not physically have the indictment to scrutinise (because it was still in the possession of the official before whom the indictment had been made).$^{73}$ In 1330 the Norfolk gaol delivery justices, Hethersett and Reppes, quashed an indictment and allowed the two accused, John le Porter and John Nottingham, to go without day, because the court felt that an indictment endorsed by the constables of the hundred (of Brothircross in this instance) was insufficient since they did not possess the requisite authority to bring persons to trial in a judgment of blood. ${ }^{74}$

The gaol delivery justices also had to negotiate the intricate world of private appeals and approvers' appeals. In private appeals of felony the facts of the case were woven into a formulaic structure which had to be recited before the justices in the exact words used. The judges were required to be vigilant and slight deviations, ambiguities or procedural lapses could cause the appeal to fail on technical grounds. ${ }^{75}$ John Pous, who appeared in court at the suit of Matilda, lately wife of William of Hoveringham of Barrow-upon-Humber, was acquitted (Matilda did not appear in court), but then asked the justices to inquire whether the appeal had been formulated maliciously. The court duly asked the jury, who found in favour of John and awarded him $£ 10$ damages. ${ }^{76}$ When self-confessed felons (approvers) came before the justices the former generally complained that the confession had been induced by officials, or made on account of diminished responsibility, or through duress of imprisonment or even under the compulsion of the justice before whom he first appeared. It was necessary for the justices to inquire from the coroner (and seek the evidence of his rolls) as well as examine the jury as to the circumstances of the appeal. ${ }^{77}$ In the case of a thief who had sought sanctuary in 
a church but was removed from there by force (on the grounds that it was never consecrated by the bishop) and then taken before the justices, the court tried to persuade him to confess and turn approver. The justices told him they believed that the verdict of the jury would go against him and he would be convicted, after which he would lose the right to speak (postquam tu convictus es tu amittes vocem).$^{78}$ Where an approver opted for trial by battle, which still remained an alternative to jury trial in appeals, the justices had to outline the detailed conditions relating to judicial combat. ${ }^{79}$

The gaol delivery rolls do not usually enter into detail about the trial other than rehearsing the indictment or accusation and providing the verdict. As with civil trials we should not be fooled by the illusion of the plea rolls into assuming that little passed between the judge and courtroom participants. The format adopted by the treatise Placita Corone is useful in this respect, since in providing material illustrative of gaol delivery proceedings it offers a glimpse of the matters not otherwise contained in the formal court record, such as the manner of the interrogation in chief by the justices. While it should be realised that the precedents in the volume are probably not real cases, but hybrids, and fairly stylised in their language and approach, they indicate the direction the justices should or might take in their questioning in a given scenario. ${ }^{80}$ The criminal cases reported from the Yorkshire eyre of 1293-4 also reveal the inquisitorial approach taken by the justices and their examination of defendant, jury and other relevant parties. ${ }^{81}$

The gaol delivery rolls occasionally demonstrate how the justices intervened and the pattern suggests they did so when, in spite of the jury's testimony as to the facts, the circumstances of a case were still unclear or there was legitimate room for doubt or indeed the jury did not know the full story. Richard Stingyn appeared in court suspected of stealing six sheep priced at $3 \mathrm{~s}$. The bench asked the jury whether the sheep allegedly stolen were near his own sheep in the field. The jury replied that they were not. They were then asked whom the sheep belonged to, but they did not know. Richard was duly acquitted. ${ }^{82}$ In cases of alleged rape or ravishment the justices often questioned the jury as to particular details omitted from their account. For instance, in a case involving the wife of Geoffrey of Stutesbury, the jury were asked if the abduction was carried out against her wish and assent. ${ }^{83}$ In another, the justices asked how old the victim was. The jury replied that she was fifteen. ${ }^{84}$ Where necessary, the justices would allow someone present in court to confirm or rebut the defendant's explanation of their actions. Richard Oliver of Buckenham, charged with stealing a cap and other goods, said that he had bought the cap from John Austin of South Walsham for three halfpennies in Norwich market place. John Austin appeared in court and admitted selling the cap to Oliver as the latter had claimed. ${ }^{85}$ Robert Mateshale said he bought the sheep he was suspected of stealing from William of Shouldham, but the latter (who was present in court) denied that he had sold them to Robert. ${ }^{86}$ The testimony of these people, therefore, was in some 
cases vital in determining the outcome where the jury were not able to provide the details.

When defendants refused to plead and deliberately remained mute, the justices sought the testimony of other prisoners in order to ascertain whether the accused possessed a tongue or could speak if he or she wanted to. ${ }^{87}$ In cases of prison breach, the keeper of the gaol was required to provide details of the escape and the measures taken to recapture the prisoners. ${ }^{88}$ There is some indication that the justices actively sought information from those jurors on the panel who had been instrumental in putting forward the original accusation. Reference to this practice comes from the trial of Chief Justice Willoughby in 1341, who, when challenged about his behaviour with respect to members of presenting and trial juries, responded by saying that speaking to those on the presenting jury, far from displaying improper motives, was in fact a reflection of standard practice. 'It is the custom for a justice to go to the indictors to encourage and inform them'. ${ }^{89}$ The justices allowed defendants to challenge jurors even though the procedure could be used to delay the trial hearing. ${ }^{90}$

It was important for the gaol delivery justices to have a secure grasp of common law defences, especially self-defence and insanity. Again, enrolled cases show how they were prepared to intervene and question the jury and/ or the defendant if the explanations rendered appeared inadequate or did not meet the strict legal criteria. Where self-defence was claimed the justices could press for more information as to the defendant's choice of weapon and whether there was any evidence of premeditation. Where insanity was alleged, the justices might need details on the duration of bouts of insanity and the frequency of any such attacks. ${ }^{91}$

In spite of (or maybe because of) the death penalty there was room for the justices to exercise discretion. This was particularly evident in cases involving young people, whose criminal liability depended upon their age at the time they committed the offence. Even though juries almost universally claimed the accused was unaware of the consequences of his or her actions, the justices still ascertained the age of young defendants. It appears, however, that there were differing views as to whether the age of criminal responsibility was twelve or fourteen..$^{92}$ It is interesting to note that a Year Book report of 1338 considers the issue of mischievous discretion, thereby revealing that criminal cases were not entirely bereft of noteworthy issues of law and procedure. It is recorded that a girl of thirteen was burned because she had killed a woman who was her mistress, which was adjudged to be treason. The argument against her being liable was based on the common law presumption that no one under age (although a precise figure was not stated) should be hanged or suffer judgment of life and limb. But, it was reported, Spigurnel had ruled that the presumption could be rebutted by evidence of malice. For where a ten-year-old child had killed his companion and concealed the body, he had demonstrated by his action that he could distinguish between evil and good and, since 'malice makes up for age' (malitia supplet 
aetatem), he duly received the death penalty. ${ }^{93}$ Since some children were convicted of homicide and theft we should presume the court found evidence of malice or recidivist behaviour. Discretion was also exercised in sentencing individuals when the offence for which they had been tried and convicted was less than capital. Theft of goods which was considered as felonious in the indictment could nevertheless be found by the jury to have possessed a value of less than a shilling, in other words, below the felony threshold. In some instances it was considered that the accused had already suffered sufficient punishment through a spell in prison prior to gaol delivery. ${ }^{94}$ Even when the jury specifically tried to excuse a theft by stating that it had been committed (through necessity) out of hunger in time of famine, the defendant was sentenced to a turn in the pillory, ${ }^{95}$ or, in another case, committed to prison for 'a night and a day until the third hour' ${ }^{96}$ The justices also assessed those defendants who claimed benefit of clergy, administered the reading test, checked they had the clerical habit and tonsure and that the letters patent from the ordinary were genuine. ${ }^{97}$ In criminal trials, therefore, although the role of the judges at first blush appears to have been extremely circumscribed, there was undoubtedly scope for interaction and questioning when judges saw it as their duty to intervene.

An understanding of law and procedure could be gained from both formaland informal training in the law. From the thirteenth century onwards this was supplemented by the medium of the written word. The increasing availability of legal literature undoubtedly helped judges and lawyers in the performance of their duties. In addition to copies of Bracton, which were used by various justices, treatises such as Fleta and Britton provided useful digests. ${ }^{98}$ The most useful and practical book for men of law involved in the administration of criminal justice was the anonymous Placita Corone (composed during the second half of the thirteenth century), which in addition to providing precedents on appeals of felony and various defences, gives instruction on how cases should be conducted at gaol delivery ${ }^{99}$ It shows how the justice should interrogate prisoners and employs different methods according to the prisoner's status and degree of knowledge and using several common scenarios tries to persuade him to confess or place himself on the jury. As the modern editor of the volume puts it, "[T]hese matters were of importance to the class of unlearned magnates, civil servants and others from whom justices of oyer and terminer and gaol delivery were drawn, and also presumably to such officials as sheriffs, coroners and bailiffs who had to perform subsidiary duties connected with court hearings. On the whole it is men of this class who would have found most profit in a treatise so elementary and yet so wide in scope. ${ }^{100}$ Whilst this chapter argues against the implication that justices of oyer and terminer and gaol delivery were entirely 'amateurs' in the field, the number of surviving manuscripts and the spectrum of persons who might find such a treatise of practical use are important to bear in mind. 
By the 1350 s statute books were widely available in a handy pocket-sized form (eclipsing the roll format used from the late thirteenth century) and could be produced to order. They usually contained common law treatises (including perhaps Placita Corone) and a textual core of statutes from Magna Carta to the significant Edwardian legislation (especially the 1285 statutes of Westminster and Winchester) and the statutes of Edward II up to $1321 .{ }^{101}$ While it does not necessarily follow in the medieval period that ownership meant actual use of a particular book, it is nevertheless possible that a number of men of law recorded as possessing statute books did actually thumb through the pages in the course of their judicial activities, men such as Edmund Deyncourt, John de Longueville and John de Northwode. ${ }^{102}$ In view of the increasing number of statutes of an administrative and judicial nature promulgated during Edward III's reign and the need for reference to statutes in court, it is significant that in 1362 justices of the peace requested that they be given copies of the 1361 statute. ${ }^{103}$ Given the number of statutes and the increasing complexity of the tasks facing the justices of the peace, it is not surprising that manuals were compiled to aid them in the performance of their duties. The earliest surviving such manual, compiled in Worcestershire in c. 1422, is not a comprehensive account of the duties and jurisdiction of the office, but (in the words of Bertha Putnam) 'does contain almost everything that justices of the quorum and the clerk of the peace ought to know. Moreover, the exclusion from the compilation of extraneous matter means that the documents form an exceedingly useful precedent or formula book easily handled, and therefore accessible for practical purposes. ${ }^{104}$ The compiler of the manual was probably John Weston, who was one of the 'working' justices of the peace in Worcestershire and Warwickshire and a justice of gaol delivery for Worcester, Warwick and Coventry gaols in the early fifteenth century. He was a common pleader of London (1402-c. 1415), recorder of Coventry (1417-c. 1434) and in 1425 became a serjeant-at-law. ${ }^{105}$

The exercise of justice on a professional basis not only spawned its own support literature, but also necessarily invoked ethical considerations. The extent to which they were an integral part of the psyche of justices in medieval England is difficult to discern. Certainly the oaths taken by the higher judiciary, which after 1290 were equally applicable to all royal justices (including assize and gaol delivery justices), charged them to do equal justice to rich and poor and avoid accepting gifts or bestowing undue favour. ${ }^{106}$ The suggestion (or accusation) that judges were open to bribery, however, was one made forcefully in much of the literary output of the period, from explicit poems such as Song on the Venality of the King's Judges dating from the thirteenth century, ${ }^{107}$ to Langland's Piers Plowman of the fourteenth century, in which the character of Lady Meed (a symbol of venality) is closely aligned with royal justice, ${ }^{108}$ to the fifteenth-century satire of The London Lickpenny, in which the litigant found that at every juncture his opportunity for justice was thwarted 
through lack of money. ${ }^{109}$ The reputation of the royal judges is not helped by high profile cases such as that of Thomas Weyland, whose involvement in a murder came to light in 1289, or of Richard Willoughby, who in 1341 was accused of selling laws 'as if they had been oxen or cows', or of John Inge who, in association with John de Molyns, was found to have perverted the course of justice. ${ }^{110}$ An Outlaw's Song of Trailbaston, which was inspired by the trailbaston commissions of 1305 , focuses at one point on the real justices of the south-western circuit and adjudicates on their characters thus:

The Martin and the Knoville are pious men,

And pray for the poor that they may have safety;

Spigurnel and Belflour are cruel men;

If they were in my jurisdiction they would not be returned. ${ }^{111}$

It was the common theme of dissatisfaction that is significant and the general perception of wrongdoing that carried weight with contemporaries, even though it might itself be misguided or wrongly applicable across the board. Where judges came into court to give advice or merely to sit on cases their presence was sometimes regarded with suspicion, particularly where they appeared as a well-wisher (benivolens) of one of the litigants. ${ }^{112}$ Similarly a parliamentary petition of 1401 assumes a connection between advice and interference and maintains that because of this justice was not being done in the courts. ${ }^{113}$ It was not necessarily anything underhand, but clearly litigants noticed and drew their own conclusions. In this respect it is interesting that royal judges were prepared to admit mistakes publicly and try to make amends. Robert Tyrwhitt, for example, who had overstepped the acceptable bounds in bringing a large retinue to an arbitration, admitted in parliament that 'he ne hath noght born hym as he sholde have doon' and agreed to provide two tuns of Gascon wine, two fat oxen and twelve sheep for dinner at Melton Ross to the aggrieved party, William, Lord Roos. His speech of apology was also recorded: 'Yet for as myche I am a justice that more than an other comun man scholde have had me more discreetly and peesfully, I knowe wele that I have failled.' 114

This chapter has provided an indication of the scope of the activities of royal justices in late medieval England. It has demonstrated that during trials juries were questioned on the facts they had presented, and matters of law and procedure were clarified. The conscientiousness of the judiciary at all levels is noticeable, even though attitudes to judges were not always entirely favourable. It has contended that the distinction 'professional' or 'amateur' is not particularly meaningful during this period and that the term 'man of law' is applicable outside the close-knit fraternity of justices operating at Westminster. The composition of judicial commissions reveals that there was a broad spectrum to the administration of justice with a proliferation of 'men of law' operating at various levels in the hierarchy of courts. 
While the participatory element should be stressed, it is also possible to see a process of professional demarcation taking place over the course of the thirteenth and fourteenth centuries. Serjeants were increasingly appointed as judges of the central courts, which in turn became predominantly staffed by laymen. It was these same men who by the mid-fourteenth century were equally responsible for the operation of the assize and gaol delivery circuits. The local men of law, who had in earlier years been appointed to gaol delivery and oyer and terminer commissions (sometimes to assize commissions and occasionally to the central courts), meanwhile found their niche in the judicial work afforded by the peace commissions. The association of county-based men of law in the quorum for peace sessions after the 1380s in turn created a clear distinction between those who by the later fourteenth and fifteenth centuries viewed their place in the magistracy as a mark of political status (or a sign of honour and favour), and had no intention of becoming involved in judicial tasks, and those whose presence was required to expedite business. These lines of development not only show the avenues to the upper echelons of judicial service and highlight how the 'working justices' were selected from (and indeed descended from earlier incarnations of) the men of law of the county, but exemplify one of the most striking evolutionary features in the history of the trial.

\section{Notes}

1 The need for such commissions increased with the suspension of the general eyre in 1294.

2 For example: P. Brand, The Origins of the English Legal Profession (London, 1992); J. H. Baker, The Legal Profession and the Common Law (London, 1986). This is addressed to some extent in N. Ramsey, 'What was the legal profession?', in M. Hicks (ed.), Profit, Piety and the Professions in Later Medieval England (Gloucester, 1990), pp. 62-71.

3 The orthodox view is presented in B. H. Putnam, 'The transformation of the keepers of the peace into the justices of the peace, 1327-1380', Transactions of the Royal Historical Society, 4th series, 12 (1929), 19-48; B. H. Putnam, 'Shire officials: keepers of the peace and justices of the peace', in J. F. Willard, W. A. Morris and W. H. Dunham (eds), The English Government at Work, 1327-1336 (3 vols, Cambridge, Massachusetts, 1940-1950), III, pp. 185-217.

4 E. Powell, 'The administration of criminal justice in late-medieval England: peace sessions and assizes', in R. Eales and D. Sullivan (eds), The Political Context of Law (London, 1987), pp. 48-59; A. Musson, Public Order and Law Enforcement: The Local Administration of Criminal Justice, 1294-1350 (Woodbridge, 1996).

5 A. J. Verduyn, 'The attitude of the parliamentary commons to law and order under Edward III', unpublished D.Phil. thesis, University of Oxford, 1991, pp. 118, $284 \mathrm{n} 42$.

6 R. V. Turner, Judges, Administrators and the Common Law in Angevin England (London, 1994), p. 199; D. J. M. Higgins, 'Judges in government and society in the reign of Edward II', unpublished D.Phil. thesis, University of Oxford, 1986, pp. 4-5. 
7 T. May, 'The Cobham family in the administration of England, 1200-1400', Archaeologia Cantiana, 82 (1967), 1-31; D. Crook, Records of the General Eyre, PRO Handbooks 20 (London, 1982), pp. 139-43.

8 G. O. Sayles (ed.), Select Cases in the Court of King's Bench,7 vols, Selden Society, 55, 57, 58, 74, 76, 82, 88 (London, 1936-71), I (55), pp. cxxix-cxxxiii, VII (88), pp. xliii-xliv.

9 P. Brand, 'Inside the courtroom: lawyers, litigants and justices in England in the later Middle Ages', in P. Coss (ed.), The Moral World of the Law (Cambridge, 2000), p. 101.

10 Brand, Origins, pp. 29, 108; Higgins, 'Judges in government', pp. 6-7, 10; Sayles (ed.) Select Cases, VII, p. xli.

11 Musson, Public Order, pp. 133, 159-60.

12 Sayles (ed.), Select Cases, VII, p. xxix: 'Then it became quite clear that the era when the benches were open to members of the civil service or to clerics or to local gentry, however talented they may have been, had come to an end by the early 1330s, if not before'.

13 R. B. Pugh, Imprisonment in Medieval England (Cambridge, 1968), pp. 257-60; A. Musson and W. M. Ormrod, The Evolution of English Justice: Law, Politics and Society in the Fourteenth Century (Basingstoke, 1998), pp. 58-62.

14 B. H. Putnam, The Place in Legal History of Sir William Shareshull (Cambridge, 1950), p. 21. See, for example: JUST 3/49/1 (combinations of John Thorpe, Simon Hethersett, John Fitton and Richard Walsingham). Many assize sessions in Edward II's reign contained one central court justice and one local man of law, for example: JUST 1/597, 852, 1378 (John Mutford with Hethersett and Sefoughel), 512A, 514, 515C, 515D (Lambert Trykingham with Cubbledyk or Fenton and Bolingbroke).

15 Musson, Public Order, pp. 1-132; for example JUST 1/97 (Cambridge), 1350 mm47, 78 (Hereford), 1350 mm43, 64d (Northants).

16 This view is espoused in R. C. Palmer, English Law in the Age of the Black Death, 1348-1381: A Transformation of Governance and Law (Chapel Hill, North Carolina, 1993).

17 For example: JUST 1/966 (gaol delivery sessions under general oyer and terminer/ trailbaston commission to Mauley, Deyncourt, Vavasour, Insula and Sutton); JUST 1/21 (special commission - Henry Spigurnel, Geoffrey de la Lee and John de la Haye - to hear and determine Beauflour v. Peyvre); JUST 1/125 (sessions held under the statute of labourers by William Polglas and Richard Cerseaux le pier).

18 JUST $3 / 161$.

19 JUST 3/147 m1 (Haywood), 154 m3, 3d (Musgrave).

20 R. Virgoe, 'The Crown and local government: East Anglia under Richard II', in F. R. H. Du Boulay and C. M. Barron (eds), The Reign of Richard II: Essays in Honour of May McKisack (London, 1971), pp. 233-5; N. Saul, Knights and Esquires: The Gloucestershire Gentry in the Fourteenth Century (Oxford, 1981), pp. 134-5; Powell, 'Peace sessions and assizes', pp. 55-6; S. Payling, Political Society in Lancastrian England: The Greater Gentry of Nottinghamshire (Oxford, 1991), pp. 177-80.

21 S. Walker, 'Yorkshire justices of the peace, 1389-1413', English Historical Review, 108 (1993), pp. 281-311.

22 For example: William Paston in Norfolk, Robert Caundyssh in Suffolk, John Burgoyne in Cambridge and Roger Hunte in Huntingdon. P. C. Maddern, Violence 
and Social Order in East Anglia, 1422-1442 (Oxford, 1991), pp. 54-64; see also S. Wright, Derbyshire Gentry in the Fifteenth Century, Derbyshire Record Society, 8 (1983), p. 98.

23 See above; Sayles regards 'the extrusion of clerics [as] an inevitable and natural sequel to the rapid advance made by laymen trained in the law' (Select Cases, IV, p. xix).

24 Turner, Judges, Administrators and Common Law, pp. 199-204, 218-20.

25 F. Broomfield (ed.), Summa confessorum (Paris and Louvain, 1968), pp. 304-5, 422-5 (quotation at p. 423), cited in Turner, Judges, Administrators and Common Law, pp. 173-4.

26 For example: A. M. Hopkinson (ed.), The Rolls of the 1281 Derbyshire Eyre, Derbyshire Record Society, 27 (Chesterfield, 2000), p. 188 (no 736).

27 Turner, Judges, Administrators and Common Lawyers, p. 177.

28 Musson, Public Order, pp. 96-8. The counties forming the Midland assize circuit were an exception as the two assize justices continued to deliver the gaols for a further couple of years.

29 John Radenhale, for instance, was commissioned on the East Anglian assize circuit (assizes: C 66/173 m27d, m20d; 174 17d; 175 m38d m35d; gaol delivery: C $66 / 175 \mathrm{~m} 35 \mathrm{~d}$ ) and is recorded as sitting for assizes at Hennowe in July and September 1331 (JUST 1/855 mm, 5, 8d). See also Thomas Sibthorpe (Musson, Public Order, pp. 116-17).

30 Sayles, Select Cases, IV, p. xix. Geoffrey Edenham may have been the same man who held a vicarage in Woodhorn in Northumberland; there were also two clerks appointed to King's Bench in 1338, though there is no evidence that they ever sat in judgment.

31 C. J. Neville, Violence, Custom and Law. The Anglo-Scottish Border Lands in the Later Middle Ages (Edinburgh, 1998), pp. 53-4, 56 n53, 58.

32 JUST 3/220/2; Maddern, Violence and Social Order, pp. 63, 220, 253-4.

33 Turner, Judges, Administrators and Common Law, p. 206.

34 See Klerman, below (chapter 3), for more detailed discussion on this.

35 JUST 1/514 m5 (Boston, Lincolnshire).

36 For example: M. Arnold (ed.), Select Cases of Trespass from the King's Courts, $1307-$ 1399, Selden Society, 100, 103 (London, 1985, 1987), II (103), pp. 378-80, 380-1, at p. 380 (petunt discretionem justiciarorum).

37 SR, I, p. 86 (c30).

38 YB 7 Edward II, p. 161.

39 P. Brand, 'The beginnings of English law reporting', in C. Stebbings (ed.), Law Reporting in England (London, 1995), pp. 1-14.

40 Brand, 'Inside the courtroom', pp. 92-3. Even where the justices subscribe to a similar view the Year Book will provide their names, e.g. 12 \& 13 Edward III, p. 290.

41 For example: YB 14 Edward III, pp. 246, 252.

42 For example: YB 3 Edward II, pp. 79, 123.

43 P. Brand (ed.), Early English Law Reports, Selden Society, 111, 112 (London, 1996), II (112), p. 322.

44 See also for example: YB 12 \& 13 Edward III, p. 350.

45 YB 8 Edward III, fol. 20, placita 9 at fol. 21 cited in Arnold (ed.), Select Cases of Trespass, ed. Arnold, I, p. xxvii. 
46 For example: YB 4 Edward II, Part 1, p. 132.

47 YB $21 \& 22$ Edward I, p. 272. The jury acquiesced and said that he was born before the solemnisation of the marriage but after the betrothal.

48 CP 40/514 m137d cited in Arnold ed., Select Cases of Trespass, I, pp. xxviii-xxix; see also YB 11 Richard II, pp. 34-5, YB 12 Richard II, pp. 184-5.

49 Not all apparent interaction should be taken at face value since, as Dr Brand cautions, some early law reports ascribe dialogue to the parties rather than to the serjeants who must have spoken for them. Brand, 'Law reporting', in Stebbings (ed.), Law Reporting, p. 4.

50 YB 2 \& 3 Edward II, p. 36.

$51 Y B 1$ \& 2 Edward II, p. 19.

52 YB 2 \& 3 Edward II, pp. xv-xvi; P. Brand, 'Legal education in England before the Inns of Court', in J. A. Bush and A. Wijffels (eds), Learning the Law: Teaching and the Transmission of Law, 1150-1900 (London, 1999), pp. 62-3.

53 YB 5 Edward II, p. 90.

54 YB 12 \& 13 Edward III, p. 170.

55 YB 3 Edward II, p. 36.

56 YB 11 Richard II, p. 177.

57 YB 12 \& 13 Edward III, p. 66.

58 YB 12 \& 13 Edward III, pp. 442-4.

59 YB 12 \& 13 Edward III, p. 298. See also ibid., p. 366, YB 11-12 Edward III, p. 136 and Sayles (ed.), Select Cases, VII, pp. 79-80.

60 Brand, 'Inside the courtroom', p. 104 (see examples cited).

61 For example: YB $1 \mathcal{E} 2$ Edward II, p. 33; YB 15 Edward III, pp. 262-4.

62 YB 1 \& 2 Edward II, p. 61; YB 3 Edward II, p. 45; YB 11 \& 12 Edward III, p. 164.

63 YB 2 \& 3 Edward II, p. xiii. The manuscript at this point has the entry "And some people thought that he meant Stonor' (who had been taking part in a debate with counsel).

64 YB 14 \& 15 Edward III, p. 114. 'Common turbary' is the right to dig turves.

65 Sayles (ed.), Select Cases, I, p. cxxxiv.

66 YB 14 Edward III, pp. 324-31. This case was actually far from summary, for since the bill of trespass had been drawn up and prosecuted various issues were raised (including Margery's claim that she was divorced and so could not be bound by Botevileyn's admission) and there were several adjournments while the court considered how to proceed.

67 R. B. Pugh, 'The duration of criminal trials in medieval England', in E. W. Ives and A. H. Manchester (eds), Law, Litigants and the Legal Profession (London, 1983), pp. 104-15; Maddern, Violence and Social Order, pp. 54-62.

68 At one time it was believed that the jury's control over evidence rendered redundant any need for communication between judge and jury. See for example: T. A. Green, Verdict According to Conscience: Perspectives on the English Criminal Trial Jury, 1200-1800 (Chicago, 1985), pp. 28-33, 66-9: 'Whether the bench questioned juries at gaol delivery ... remains unclear' (ibid., p. $68 \mathrm{n} 8$ ).

69 For example: JUST 3/117 m7d.

70 Two such instances reached the Court of King's Bench: Sayles (ed.), Select Cases, VI, pp. 21-5, 133.

71 JUST $3 / 49 / 2 \mathrm{~m} 8 \mathrm{~d}$.

72 JUST $3 / 48 \mathrm{~m} 33$. 
73 For example: JUST 3/48 m11d; 49/1 m2.

74 JUST 3/125 m1.

75 For a more detailed discussion see A. Musson, Medieval Law in Context: The Growth of Legal Consciousness from Magna Carta to the Peasants' Revolt (Manchester, 2001), pp. 154-6 and on changes in judicial policy towards appeals of felony see D. Klerman, 'Settlement and the decline of private prosecution in thirteenthcentury England', Law and History Review, 19 (2001), 38-53.

76 JUST 3/32/1 m4.

77 For example: JUST 3/134 m64, 156 m3; YB 30-31 Edward I, pp. 543-5; YB 11 \& 12 Edward III, p. 626; see also A. J. Musson, 'Turning king's evidence: the prosecution of crime in late medieval England', Oxford Journal of Legal Studies, 19 (1999), 467-79.

78 YB 30-31 Edward I, p. 541.

79 See for example the account in J. Gairdner (ed.), Gregory's Chronicle: The Historical Collections of a Citizen of London, Camden Society, new series, 17 (1876), pp. 199202.

80 J. M. Kaye (ed.), Placita Corone, or La Corone pledee devant justices, Selden Society Supplementary Series, 4 (London, 1966), pp. xxiii, xxxv, 17-22. See Klerman, chapter 3 below, for an example of dialogue.

81 YB 30-31 Edward I, pp. 528-45. Although the editor says the cases were taken from the Cornish eyre of 1302, the officials and place names are specific to Yorkshire: see Brand (ed.), Early English Law Reports, I, p. xxii n18.

82 JUST $3 / 48 \mathrm{~m} 20$.

83 JUST $1 / 966 \mathrm{~m} 11 \mathrm{~d}$.

84 JUST $3 / 47 / 3 \mathrm{~m} 5$.

85 JUST 3/49/1 m21. The bailiff of Blofield, Roger of Hakeford, then testified that Austin had been indicted before the sheriff for the theft of the aforesaid cap.

86 JUST $3 / 49 / 1 \mathrm{~m} 38$.

87 JUST $3 / 51 / 4 \mathrm{~m} 7$.

88 For example: JUST 3/49/1 m49.

89 YB 14 \& 15 Edward III, p. 260. This assumes also that there were some of the indictors on the trial jury. Although this was a common feature in the days of the eyre, by the mid-fourteenth century it was not necessarily the case and, moreover, during the course of the early fourteenth century was increasingly frowned upon, culminating in the statute of 1352. It is noticeable that in the 1360 s certain sheriffs when empanelling jurors assiduously excepted those who were indictors - for further discussion see A. Musson, 'Twelve good men and true? The character of early fourteenth-century juries', Law and History Review, 15 (1997), 135-9 and Musson, Medieval Law in Context, pp. 118-19.

90 JUST 3/49/1 m38; $117 \mathrm{~m} 8 \mathrm{~d}$.

91 N. D. Hurnard, The King's Pardon for Homicide before ad 1307 (Oxford, 1969), pp. 76-8, 92-6, 159-70.

92 Compare, for example: JUST 3/47/3 m1, 47/2 m6, 6d, 96 m3; A. W. G. Kean, 'The history of the criminal liability of children', Law Quarterly Review, 53 (1937), 366-8.

93 YB 12 Edward III, p. 627.

94 JUST $3 / 110 \mathrm{~m} 8 \mathrm{~d}$.

95 JUST $3 / 47 / 2 \mathrm{~m} 7$. 
96 JUST 3/51/4 m8.

97 For example: JUST 3/48 m20; $117 \mathrm{~mm} 9 \mathrm{~d}, 14$.

98 These are printed in S. Thorne (ed.), Bracton on the Laws and Customs of England (4 vols, Cambridge, Massachusetts, 1968-1977); H. G. Richardson and G.O. Sayles (eds), Fleta, Selden Society, 72, 89, 99 (London, 1955-1984); F. M. Nichols (ed.), Britton (London, 1865).

99 Placita Corone, pp. ix- $\mathrm{x}$.

100 Placita Corone, p. xxiii.

101 D. C. Skemer, 'From archives to the book trade: private statute rolls in England, 1285-1307', Journal of the Society of Archivists, 16 (1994), 194-9; D. C. Skemer, 'Reading the law: statute books and the private transmission of knowledge in late medieval England', in Bush and Wijffels (eds), Learning the Law, pp. 113-32.

102 I am grateful to Dr J. Arkenburg for allowing me to see his list of book owners (1272-1350). Deyncourt was active in Lincolnshire (e.g. JUST 3/55/2), Longueville in Northamptonshire (e.g. JUST 3/51/3) and Northwode in Kent (e.g. JUST 3/109).

103 Verduyn, 'Attitude of the parliamentary commons', p. 145.

104 B. H. Putnam, 'Early treatises on the practice of the justices of the peace in the fifteenth and sixteenth centuries', Oxford Studies in Social and Legal History, 7 (Oxford, 1924), 60-93.

105 Ibid., pp. 73-80.

106 P. Brand, The Making of the Common Law (London, 1992), pp. 148-52. For the debate on compromises and influences on local justice in the later fourteenth and fifteenth centuries see Musson and Ormrod, Evolution, pp. 173-91.

107 P. Coss (ed.), Thomas Wright's Political Songs (Cambridge, 1996), pp. 224-30.

108 A. P. Baldwin, The Theme of Government in Piers Plowman (Woodbridge, 1981), pp. 24-34.

109 R. H. Robbins (ed.), Historical Poems of the Fourteenth and Fifteenth Centuries (New York, 1959), pp. 130-4.

110 See P. Brand, 'Chief justice and felon: the career of Thomas Weyland', in Eales and Sullivan (eds), The Political Context of Law, pp. 26-47; YB 14 \& 15 Edward III, p. 258; N. Fryde, 'A medieval robber baron: Sir John Molyns of Stoke Poges', in R. F. Hunnisett and J. B. Post (eds), Medieval Legal Records Edited in Memory of C. A. F. Meekings (London, 1978), pp. 197-222.

111 R. B. Dobson and J. Taylor, Rymes of Robin Hood: An Introduction to the English Outlaw (revised edition, Stroud, 1997), p. 252. It is interesting that the two justices singled out for criticism were from the central courts. There are surviving plea rolls of sessions held by these justices in Wiltshire (JUST 1/1015).

112 Brand, 'Inside the courtroom', pp. 100-1.

113 RP, III, p. 59 [2 Henry IV no 95]: 'The Commons pray that in consideration of the very great mischiefs which occur in your Court of Chancery, because, for the discussion of all pleas relating to matters traversed in the said court, your judges of your Benches called the King's Bench and the Common Bench are drawn into the said Chancery out of their own places, in aid of the discussion of the said matters therein, to the great delay of the administration of the common law of your kingdom and to the very great damage of your lieges ...'

114 RP, III, pp. 649-51. 